\title{
Sustainable strategies and methods for the energetic improvement of social housing stock in Italy
}

\author{
S. Brunoro \\ University of Ferrara, Department of Architecture, \\ Architettura Energia Research Centre, Italy
}

\begin{abstract}
This paper seeks to investigate the use of sustainable strategies of intervention in the refurbishment of social suburban building stock considering some public buildings in Emilia Romagna region of ACER (Emilia Romagna housing company) ownership. In this study, interventions on the envelope and the installations, in order to improve architectural and energetic performance following the new European Energy Standards for energy savings, have been considered. Besides the technology and architectural result, an evaluation of the costs of the interventions and their payback was done; this should be very important considering the nature of the ownership.

Examples of interventions pointed to the use of renewable energies and sustainable technologies for building envelopes (external thermal insulation, ventilated façades, and greenhouses) are examined. The investigation is based on a range of examples developed during the course of energetic control of buildings at the Faculty of Architecture of Ferrara and with the support of ACER Ferrara and Reggio Emilia. Social buildings owned by public companies are very popular in the Italian suburbs. These large and highly populated living units clearly represent the main examples of energy consumption in the building sector. Performing envelopes and renewable energies are the most useful strategies to improve not only the energetic balance, but also the architectural value of these buildings.

The approach carried out was step by step, starting from the easiest and cheapest operations (e.g. replacement of windows) up to the more expansive (e.g. photovoltaic panels). This approach can be helpful to public administrations to manage interventions by considering their incidence on the overall balance.
\end{abstract}


Examples presented in this paper show that sustainable technologies, commonly used in new constructions and based on the concept of a low environmental impact, can be also employed in the refurbishment of existing buildings, which is the main challenge for the global reduction of $\mathrm{CO}_{2}$ emissions.

Keywords: social housing, renewable energies, sustainable technologies, bioclimatic architecture, energy retrofit.

\section{Introduction}

Suburban building estates make up about $40 \%$ of all Italian building stock. These urban areas are primarily residential and are home to a large part of the population in Italy. The large part of these social housing is managed by public companies: this means that residents do not own apartments, but they are tenants with low incomes. All the maintenance and refurbishment operations are managed by public companies: this generates, in the most cases, very low profile of the buildings.

Most the buildings of the suburban areas - generally multi-family housing blocks consisting of small apartments - were completed after 1950 using lowcost technologies and are often characterized by very poor quality, which contributes to the social decay of suburbs. With the new Italian energy efficiency regulation (D.Lgs 311/06) building are forced to respect restricted standards for energy saving, that none of these building can respect. In the last ten years building envelope has become very important in the overall energy balance, as a dynamic surface able to optimize its performance in relation to different climatic inputs. In this sense it will be desirable to manage the required refurbishment actions in the direction of the passive solar gaining, the natural cooling and other relevant sustainable technologies for building envelopes. Moreover the use of renewable energies and of high-efficient installation should greatly improve energy saving.

The experience carried out by the Department of Architecture of the University of Ferrara in cooperation with ACER (Emilia Romagna housing public company) was to assess the state of decay of a large part of social buildings between Ferrara and Reggio Emilia and to suggest architectural and technical interventions in order to meet new requirements both in terms of energy efficiency and architectural value. The main aim was to provide strategies of refurbishment mainly considering feasibility, real conditions and the cost of construction besides of the new energy efficiency standard.

Renovating façades often coincides with changes in the architectural appearance of a building block, and large investments to improve the quality of the building envelope are justified if the building block, as a whole, can meet future requirements. Moreover, replacing installations, mainly considering the contribution of renewable energies, should be evaluated in terms of initial costs/payback period. The focus was therefore widened to comprise technical and architectural aspects as well, and to give indications to public companies on the feasibility of some interventions comparing to others. 


\section{Acer buildings in the Emilia Romagna region: a very energetic inefficient building stock}

First of all, the energetic diagnosis on the building stock was done: main typologies, main technologies, plants and installations were considered in order to provide a yearly energy balance that should be the starting point to elaborate an energy retrofit strategy.

A sample of 10 buildings, between the provinces of Ferrara and Reggio Emilia was examined, by means of:

- a direct survey, to collect necessary information;

- specific software to estimate the energetic performance of the building $(\mathrm{kWh} /$ square meter/year), in which all the information were filled in. Energetic performance regards winter season only, (heating and hot water supply) as at the moment it is the only mandatory for Italian regulation. Energy balance considers all the factors that influence the energy performance of a building: surface and volume (shape/dimension of the building), orientation and solar gains, walls, windows, floors and roof materials transmission ( $U$ value), type of fuel and plants, global energy consumptions. Each building can be classified in an "energy class" that expresses its energy performance that range to the "G" class (worst class) to the "A" class (best class).

The most part of the buildings were built between '60 and '70 years. Main typology is multi - storey building blocks that can range from 4 to 8 floors high composed of 2 to 4 apartments for floor. Staircases are generally in the middle, and normally no elevator is installed.

Bearing structure of steel reinforced concrete beams and in situ concrete pillars were the main building technologies used. To this skeleton, façades and partition walls are added, using hollow brick blocks. The floor systems vary: reinforced concrete slab floors as well as floors constructed with prestrengthened beams with filling blocks are both commonly used. In some cases, even the assembly of large panels is an applied technique. The large storey-high slabs of prefabricated concrete were joined and fixed together with in situ concrete. Facades are generally realized in perforated brickwork or prefabricated concrete panels. Brick walls are single or, rarely, double layer with $4 \mathrm{~cm}$ air cavity. Dimensions ranges between 27 (single) to 32 (double) $\mathrm{cm}$. Only in few cases there is thermal insulation in the air cavity. External and internal layer is, for the most part, plaster. Panels are single or multi layer and finished by gray smooth concrete or white or yellow marble chips. The most common materials used for window frames are wood and aluminum; rarely plastic. The most part of housing stock was built before the first petrol crisis in 1973 and the consequent law n. 373/1976, so it has single glazed window panes [1,2].

Both flat and pitched roofs are used. The structure is generally the same used for the floors: trestle floor beams and hollow floor blocks or prefabricated concrete panels. Flat roofs are usually finished with two layers of asphalt paper and a $4 \mathrm{~cm}$ thick layer of gravel. Slope roofs are finished with roof tiles. 
Gas methane is the most used fuel for heating. Centralized boilers, in common boiler rooms, are present in almost all the buildings examined. The remaining buildings have single boilers for each apartment. District heating is present in three case studies. An in depth energetic diagnosis highlighted that the above mentioned building stock is very lacking as for the energy efficiency (all the building were classified in $\mathrm{G}$ class) as for the architectural quality (bad state of conservation, decay of plaster and windows).

Table 1: $\quad$ Basic data related to a sample of 10 suburban multi storey building blocks in Ferrara, Reggio Emilia and Bologna (Italy).

\begin{tabular}{|c|c|c|c|c|}
\hline BUILDING & WALLS & WINDOWS & PLANTS & $\begin{array}{c}\text { ENERGY PER- } \\
\text { FORMANCE } \\
\text { (KWh/ } / \mathrm{m}^{2} / \text { year) }\end{array}$ \\
\hline $\begin{array}{l}\text { 1. Via Pietro Lana } \\
\text { Ferrara }\end{array}$ & $\begin{array}{l}\text { Internal plaster, hol- } \\
\text { low brick blocks and } \\
\text { exposed bricks } 26 \\
\mathrm{~cm} U=1,36 \mathrm{~W} / \mathrm{mq} \\
\mathrm{K}\end{array}$ & $\begin{array}{l}\text { Wood frame with } \\
\text { single panes glass } \\
\mathrm{U}=4,8 \mathrm{~W} / \mathrm{mq} \mathrm{K}\end{array}$ & District heating & $\begin{array}{l}272 \mathrm{Kwh} \mathrm{m} 2 \mathrm{a} \\
\text { Sqm } 1850\end{array}$ \\
\hline $\begin{array}{l}\text { 2. Via Grosoli } \\
\text { Ferrara }\end{array}$ & $\begin{array}{l}\text { Exposed brick wall } \\
13,5 \mathrm{~cm} \\
\mathrm{U}=1,82 \mathrm{~W} / \mathrm{mq} \mathrm{K}\end{array}$ & $\begin{array}{l}\text { Aluminum frame } \\
\text { with single glass }\end{array}$ & $\begin{array}{l}\text { Single boiler - one } \\
\text { for apartment }\end{array}$ & $\begin{array}{l}320 \mathrm{Kwh} \text { m2a } \\
\mathrm{Sgm} 250\end{array}$ \\
\hline $\begin{array}{l}\text { 3. Via Ungarelli - } \\
\text { Foro Boario Ferrara }\end{array}$ & $\begin{array}{l}\text { Brick wall }+3 \mathrm{~cm} \\
\text { etics }\end{array}$ & $\begin{array}{l}\text { Plastic frame with } \\
\text { single glass }\end{array}$ & $\begin{array}{l}\text { Single boiler - one } \\
\text { for apartment }\end{array}$ & $\begin{array}{l}280 \mathrm{Kwh} \text { m2a } \\
\mathrm{Sgm} 260\end{array}$ \\
\hline $\begin{array}{l}\text { 4. Via Medini } \\
\text { Fenrara }\end{array}$ & $\begin{array}{l}\text { Two layers hollow } \\
\text { brick blocks, plaster } \\
\text { finishing }\end{array}$ & $\begin{array}{l}\text { Aluminum frame } \\
\text { with single glass }\end{array}$ & $\begin{array}{l}\text { Centralized boiler - } \\
\text { air heater }\end{array}$ & $\begin{array}{l}215 \mathrm{Kwh} \text { m2a } \\
\mathrm{Sgm} 600\end{array}$ \\
\hline $\begin{array}{l}\text { 5. Via Barlaam } \\
\text { Ferrara }\end{array}$ & $\begin{array}{l}\text { Hollow brick blocks } \\
\text { and exposed bricks } \\
26 \mathrm{~cm} \mathrm{U} \quad \mathrm{U}=1,36 \\
\mathrm{~W} / \mathrm{mq} \mathrm{K}\end{array}$ & $\begin{array}{l}\text { Wooden frame with } \\
\text { single panes glass } \\
\mathrm{U}=3,7 \mathrm{~W} / \mathrm{mq} \mathrm{K}\end{array}$ & District heating & $\begin{array}{l}187 \mathrm{Kwh} \text { m2a } \\
\text { Sqm } 4692\end{array}$ \\
\hline $\begin{array}{l}\text { 6. Via Monti - Foro } \\
\text { Boario } \\
\text { Ferrara }\end{array}$ & $\begin{array}{l}\text { Hollw brick blocks } \\
30 \mathrm{~cm} \\
\mathrm{U}=0,97 \mathrm{~W} / \mathrm{mq} \mathrm{K}\end{array}$ & $\begin{array}{l}\text { Wooden frame with } \\
\text { single panes glass } \\
\mathrm{U}=3,7 \mathrm{~W} / \mathrm{mg} \mathrm{K}\end{array}$ & $\begin{array}{l}\text { Single Boiler - one } \\
\text { for apartment }\end{array}$ & $\begin{array}{l}326 \mathrm{Kwh} \text { m2a } \\
\text { Sqm } 415\end{array}$ \\
\hline $\begin{array}{l}\text { 7. Barca Building } \\
\text { Bologna }\end{array}$ & $\begin{array}{l}\text { Hollow brick blocks } \\
\text { and exposed bricks } \\
30 \mathrm{~cm} \\
\mathrm{U}=1,26 \mathrm{~W} / \mathrm{mq} \mathrm{K}\end{array}$ & $\begin{array}{l}\begin{array}{l}\text { Plastic frames with } \\
\text { double layer glass } \\
\text { panes }\end{array} \\
\mathrm{U}=2,2 \mathrm{~W} / \mathrm{mq} \mathrm{K}\end{array}$ & District heating & $\begin{array}{l}273 \mathrm{Kwh} \mathrm{m} 2 \mathrm{a} \\
\text { sqm } 3372\end{array}$ \\
\hline $\begin{array}{l}\text { 8. Via due canali } 5 \\
\text { Reggio Emilia }\end{array}$ & $\begin{array}{l}\text { Hollow brick blocks } \\
28 \mathrm{~cm} \\
\mathrm{U}=1,4 \mathrm{~W} / \mathrm{mq} \mathrm{K}\end{array}$ & $\begin{array}{l}\text { Wooden frames with } \\
\text { single layer panes } \\
\mathrm{U}=3,2 \mathrm{~W} / \mathrm{mq} \mathrm{K}\end{array}$ & $\begin{array}{l}\text { Centralized boiler in } \\
\text { separate boiler room }\end{array}$ & $\begin{array}{l}315 \mathrm{Kwh} \text { m2a } \\
\mathrm{sqm} 500\end{array}$ \\
\hline $\begin{array}{l}\text { 9. Via Maramotti } 25 \\
\text { Reggio Emilia }\end{array}$ & $\begin{array}{l}\text { Concrete prefab pa- } \\
\text { nels with insulating } \\
\text { layer } 24 \mathrm{~cm} \mathrm{U}=0,67 \\
\mathrm{~W} / \mathrm{mg} \mathrm{K}\end{array}$ & $\begin{array}{l}\text { Aluminium frames } \\
\text { with double glass } \\
\mathrm{U}=2,9 \mathrm{~W} / \mathrm{mq} \mathrm{K}\end{array}$ & $\begin{array}{l}\text { Centralized boiler in } \\
\text { separate boiler room }\end{array}$ & $\begin{array}{l}129 \mathrm{Kwh} \mathrm{m} 2 \mathrm{a} \\
\mathrm{sqm} 850\end{array}$ \\
\hline $\begin{array}{l}\text { 10. Tito Minniti } \\
\text { Ferrara }\end{array}$ & $\begin{array}{l}\text { Brick wall with plas- } \\
\text { ter } 28 \mathrm{~cm} \mathrm{U}=1,45 \\
\mathrm{~W} / \mathrm{mq} \mathrm{K}\end{array}$ & $\begin{array}{l}\text { Aluminium frames } \\
\text { with single glass } \\
\mathrm{U}=3,9 \mathrm{~W} / \mathrm{mq} \mathrm{K}\end{array}$ & $\begin{array}{l}\text { Single Boiler - one } \\
\text { for apartment }\end{array}$ & $\begin{array}{l}241 \mathrm{Kwh} \mathrm{m} 2 \mathrm{a} \\
\text { sqm } 2238,93\end{array}$ \\
\hline
\end{tabular}




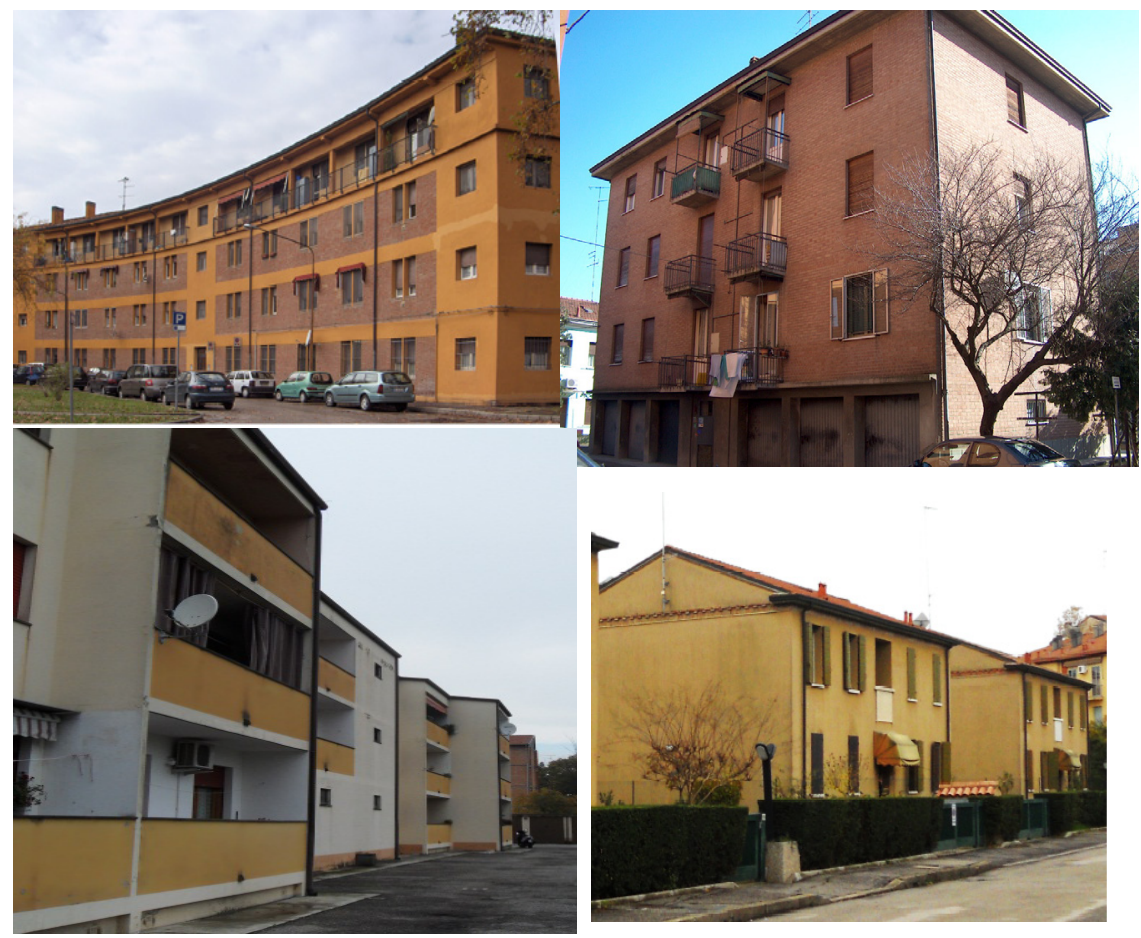

Figure 1: $\quad$ Profile of suburban multi storey building blocks.

\section{Main refurbishment actions: from best price to best practice}

Different refurbishment purposes were considered, taking in account a progressive modus operandi in terms of:

- Feasibility (e.g.: occupant diseases during building site);

- Initial investment (necessity to reduce refurbishment costs due to the public ownership);

- Improving energy efficiency and energy saving benefits in the long period;

- Increasing architectural value.

By considering these variables, a "best price to best practice" strategy was developed. This means progressive interventions, starting from the most economic solution to a best practice solution, in which a complete refurbishment is considered.

Should the more expensive solution be the most convenient in term of initial investment/payback? Some different scenarios have been examined in order to answer to this question. The aim of the study was to give indications that can be helpful to designers and public administration to guide their investments on refurbishment intervention to maximize costs and benefits. 
Main refurbishment actions from the minimum intervention to the total refurbishment are below examined.

\subsection{Heat generator substitution}

In the hypothesis of the minimum intervention, the replacing of old heat generators with more efficient ones was considered. In the most cases heat generators were very old, and do not fulfill energy efficiency new regulations. This evaluation was done both in the case of autonomous boilers (one for each apartment) than in case of centralized heat generator. The strategy considers the minimum threshold of feasibility, so with only essential modifications of the heating system network. It was considered to install condensation boilers: they can maximize energy performance due to their very high performance (about 91\%- $93 \%$ of efficiency in comparison to an $80-85 \%$ for a traditional boiler). These boilers allow about $25-30 \%$ of energy saving with traditional heaters, but they express their maximum performance with low temperature installation (e.g. floor heater). Also in the case of centralized heating - in a common boiler room - the substitution with high efficiency boilers was supposed.

In all the buildings the incidence of boiler substitution in the global energy balance can be estimate in an energy saving of about $15-20 \%$. The result is, in more or less of the case studies, the improvement of the energetic performance of about $60-90 \mathrm{kWh} / \mathrm{m}^{2} /$ year (in the most cases buildings remain in the same class, mostly $\mathrm{G}$ and $\mathrm{F}$ class). This kind of intervention can be done with an affordable initial cost, with a payback period of not more than 5 years. Payback period was calculated by considering Euro/year saved due to the reduction of methane consumption - also with an actualization of inflation rate - in comparison with the initial investment cost for the energy retrofit intervention. In all the cases examined, the cost/benefits of this intervention should not be remarkable in terms of energy efficiency.

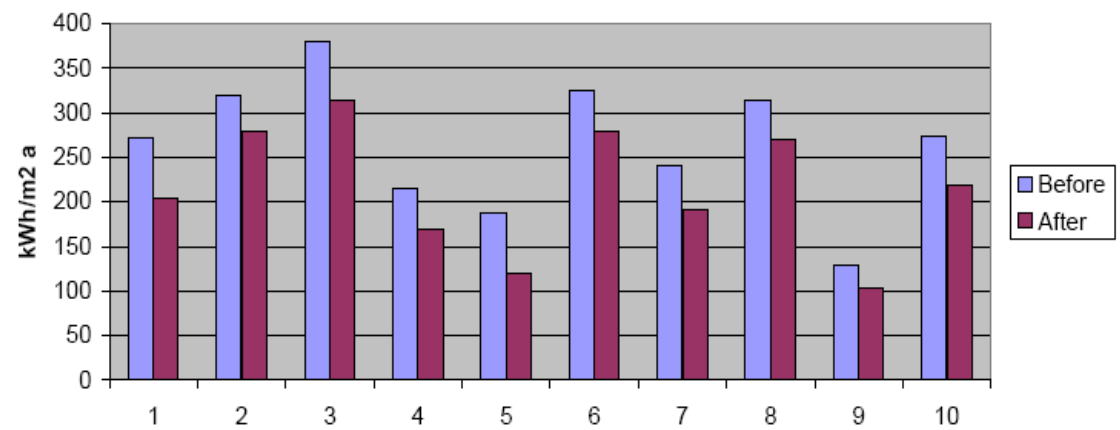

Figure 2: Energy saving $\left(\mathrm{kWh} / \mathrm{m}^{2} \mathrm{a}\right)$ for changing boilers in the 10 selected case studies. 


\subsection{Replacing of windows}

Replacing of windows is the first intervention considered in order to improve energy efficiency of the envelope. This intervention should be done in the most cases without confining the occupants in other apartments, and with limited disease for the inhabitants. The hypothesis of refurbishment considered double layer glass windows with low-e glass $\left(\mathrm{U}=1,3 \mathrm{~W} / \mathrm{m}^{2} \mathrm{~K}\right)$.

Anyway, a partial intervention on the envelope may create some problems that have necessarily taken in account. In the most cases, opaque surface is so extended and its thermal transmittance is so lacking that the incidence of windows in the overall façade is not remarkable, moreover improving windows performance without considering walls insulation may reinforce the thermal bridges between the joint window frame-wall [1].

An in depth evaluation shows how the incidence of replacing windows on the energetic performance has just been done is about 20-25\%. An investment of about 300 Euros for windows, can improve energy performance of about 70 $90 \mathrm{kWh} / \mathrm{m}^{2} /$ year (in the most cases buildings remain in the same class, mostly $\mathrm{G}$ and $\mathrm{F}$ class). By considering the initial cost (that can range from 24.000 to 40.000 , depending on the case study), payback period can range from 6 to 11 years.

Cubic meters of methane saved and euro/year saved becomes remarkable in the case of much extended buildings (more than 1000 square meters), with a large number of windows. Although, in these cases, the cost of the intervention grows. By considering cost-benefits balance, it should be said that an improvement of the whole envelope should be desirable, as initial costs should be amortized with a better energy performance.

Table 2: Replacing of windows: energy performance, money saved and payback period.

\begin{tabular}{|l|l|r|r|r|r|r|r|r|r|r|}
\hline & $\begin{array}{l}\text { Pietro } \\
\text { Lana } \\
\text { Ferrara }\end{array}$ & $\begin{array}{l}\text { Grosoli } \\
\text { Ferrara }\end{array}$ & $\begin{array}{l}\text { Ungarelli } \\
\text { Ferrara }\end{array}$ & $\begin{array}{l}\text { Medini } \\
\text { Ferrara }\end{array}$ & $\begin{array}{l}\text { Barlaam } \\
\text { Ferrara }\end{array}$ & $\begin{array}{l}\text { Monti } \\
\text { Ferrara }\end{array}$ & $\begin{array}{l}\text { Tito Min- } \\
\text { niti } \\
\text { Ferrara }\end{array}$ & $\begin{array}{l}\text { Due } \\
\text { Canali } \\
\text { Reggio } \\
\text { Emilia }\end{array}$ & $\begin{array}{l}\text { Maramotti } \\
\text { Reggio } \\
\text { Emilia }\end{array}$ & $\begin{array}{l}\text { Barca } \\
\text { Bologna }\end{array}$ \\
\hline $\begin{array}{l}\mathrm{kWh} / \mathrm{m}^{2} \\
\text { year be- } \\
\text { fore }\end{array}$ & 272 & 320 & 380 & 215 & 187 & 326 & 241 & 315 & 129 & 273 \\
\hline $\begin{array}{l}\mathrm{kWh} / \mathrm{m}^{2} \\
\text { year after }\end{array}$ & 200 & 240 & 285 & 172 & 125 & 260 & 192 & 252 & 103 & 218 \\
\hline $\begin{array}{l}\text { Mc meth- } \\
\text { ane/year } \\
\text { saved }\end{array}$ & 12.000 & 2.000 & 2.500 & 2.580 & 19.700 & 2.739 & 10.970 & 3.150 & 2.210 & 18.500 \\
\hline $\begin{array}{l}\text { Euro/year } \\
\text { saved }\end{array}$ & 10.000 & 1.660 & 2.050 & 2.100 & 16.300 & 2.273 & 9.100 & 2.614 & 1.834 & 15.390 \\
\hline $\begin{array}{l}\text { Payback } \\
\text { period } \\
\text { year) }\end{array}$ & 7 & 10 & 11 & 8 & 7 & 10 & 9 & 8 & 9 & 6 \\
\hline
\end{tabular}




\subsection{Improving envelope performance: external thermal insulation coatings}

External thermal insulation coating (ETICS) is one of the most suitable solutions for improving thermal insulation in walls. It consists of an external covering with insulating panels, fixed to the existing surfaces through wedges and binder, then armed with special net and completed with a thin layer of plaster [2]. Energy regulation standards in Emilia Romagna region for walls is expressed with a maximum thermal transmittance ( $\mathrm{U}$ value) of $0,34 \mathrm{~W} / \mathrm{m} 2 \mathrm{~K}$. In the most cases, initial wall transmittance was higher that $1,2 \mathrm{~W} / \mathrm{m} 2 \mathrm{~K}$ : this means that $12 \mathrm{~cm}$ of extruded polystyrene insulation layer was considered.

The application of ETICS became in the last ten years a popular measure to improve the energy performance and the weather resistance of façades in the building stock. This raises questions about the durability of ETICS compared to other types of thermal insulation. Even if it is frequently supposed that the small thickness of the exterior plaster and a smooth insulation material as substrate are possible causes for damage from mechanical impact, many experiences can demonstrate that the costs and frequency of maintenance for ETICS are less than those of traditional wall structures [3].

The improvement of energy efficiency of buildings by adding a thermal insulation layer is quite appreciable. In the case of minimum standard requirements (Emilia Romagna regulation standard) global thermal transmittance of walls has been reduced of one third, with a global reduction of about (D energy class for the majority of the case studies). In the case of best performance (low energy building standard) a good energetic class (C) can be obtained.

An average ETIC cost (complete realization) can range from 60 to $90 \mathrm{Euro} / \mathrm{m}^{2}$.

Table 3: Adding ETICS, energy performance, money saved and payback period.

\begin{tabular}{|l|l|r|r|r|r|r|r|l|r|l|}
\hline & $\begin{array}{l}\text { Pietro } \\
\text { Lana } \\
\text { Ferrara }\end{array}$ & $\begin{array}{l}\text { Grosoli } \\
\text { Ferrara }\end{array}$ & $\begin{array}{l}\text { Ungarelli } \\
\text { Ferrara }\end{array}$ & $\begin{array}{l}\text { Medini } \\
\text { Ferrara }\end{array}$ & $\begin{array}{l}\text { Barlaam } \\
\text { Ferrara }\end{array}$ & $\begin{array}{l}\text { Monti } \\
\text { Ferrara }\end{array}$ & $\begin{array}{l}\text { Tito Min- } \\
\text { niti } \\
\text { Ferrara }\end{array}$ & $\begin{array}{l}\text { Due } \\
\text { Canali } \\
\text { Reggio } \\
\text { Emilia }\end{array}$ & $\begin{array}{l}\text { Maramotti } \\
\text { Reggio } \\
\text { Emilia }\end{array}$ & $\begin{array}{l}\text { Barca } \\
\text { Bologna }\end{array}$ \\
\hline $\begin{array}{l}\mathrm{kWh} / \mathrm{m}^{2} \\
\text { year be- } \\
\text { fore }\end{array}$ & 272 & 320 & 380 & 215 & 187 & 326 & 241 & 315 & 129 & 273 \\
\hline $\begin{array}{l}\mathrm{kWh} / \mathrm{m}^{2} \\
\text { year after }\end{array}$ & 170 & 210 & 235 & 115 & 100 & 176 & 138 & 210 & 49 & 200 \\
\hline $\begin{array}{l}\text { Mc meth- } \\
\text { ane/year } \\
\text { saved }\end{array}$ & 18.870 & 2.750 & 3.770 & 6.000 & 40.820 & 6.225 & 23.060 & 5.250 & 6.800 & 24.615 \\
\hline $\begin{array}{l}\text { Euro/year } \\
\text { saved }\end{array}$ & 15.662 & 2.282 & 3.129 & 4.980 & 33.880 & 5.166 & 19.140 & 4.350 & 5.644 & 20.400 \\
\hline $\begin{array}{l}\text { Payback } \\
\text { period } \\
\text { (year) }\end{array}$ & 10 & 9.8 & 8 & 11 & 12 & 7 & 10.5 & 10.3 & 12 & 13 \\
\hline
\end{tabular}


The reduction of fuel consumption in the case studies examined is shown above. An average of $100 \mathrm{kWh} / \mathrm{m}^{2} /$ year was saved, with a jump from G-F class to $D$ class. This means about $\mathrm{m}^{3}$ of gas methane for an average money saving of about Euros/year. Payback period is, in the most cases, not higher than 10 years.

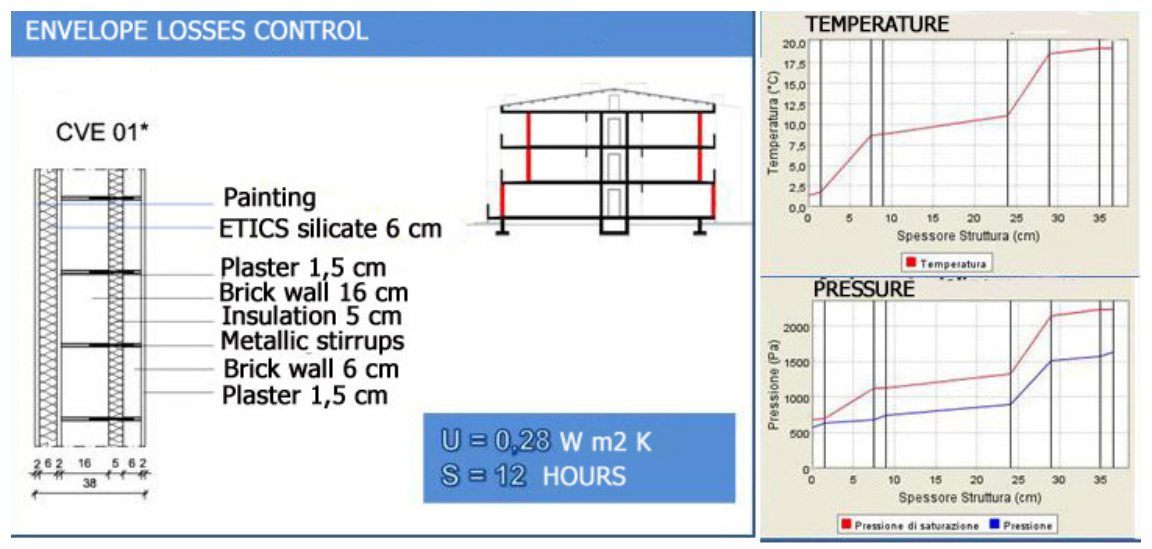

Figure 3: Adding external thermal insulation on existing wall in Via Medini case study: global thermal transmittance, temperature and condensation control.

\subsection{Photovoltaic systems}

In eight of the ten case studies, the production of electricity by using a photovoltaic installation was evaluated. Two of them were not considered convenient due to the non optimal orientation of the roof that could not offer relevant values of energy production. A photovoltaic system uses one or more panels to convert sunlight into electricity. It consists of multiple components, including the photovoltaic modules, mechanical and electrical connections and mountings and means of regulating or modifying the electrical output. Photovoltaic performance in improving energy balance of the buildings was considered by:

- Assessing the suitability of the building (e.g. roof/façade/balcony) for photovoltaic solar installation;

- Site survey: orientation, latitude, yearly hours/sun, shadow range for photovoltaic best efficiency;

- Photovoltaic installation design (square meters, position, angle);

- Estimate of yearly energy production;

- Initial investment cost and energy saving cost for payback period evaluation.

In all the examined case studies it can be said that the use of photovoltaic system installation should be convenient, as even if initial costs may be very high, energy production due to the best conditions of orientation/installation assure a payback period not over to 20 years, that is the maximum threshold of convenience for PV installation. 
Table 4: $\quad$ Photovoltaic system installation, energy performance, money saved and payback period.

\begin{tabular}{|l|c|c|c|c|c|c|c|c|c|c|}
\hline & $\begin{array}{l}\text { Pietro } \\
\text { Lana } \\
\text { Ferrara }\end{array}$ & Frosoli & $\begin{array}{l}\text { Ungarelli } \\
\text { Ferrara }\end{array}$ & $\begin{array}{l}\text { Medini } \\
\text { Ferrara }\end{array}$ & $\begin{array}{l}\text { Barlaam } \\
\text { Ferrara }\end{array}$ & $\begin{array}{l}\text { Monti } \\
\text { Ferrara }\end{array}$ & $\begin{array}{l}\text { Tito } \\
\text { Minniti } \\
\text { Ferrara }\end{array}$ & $\begin{array}{l}\text { Due } \\
\text { Canali } \\
\text { Reggio } \\
\text { Emilia }\end{array}$ & $\begin{array}{l}\text { Maramotti } \\
\text { Reggio } \\
\text { Emilia }\end{array}$ & $\begin{array}{l}\text { Barca } \\
\text { Bologna }\end{array}$ \\
\hline $\begin{array}{l}\text { Photo- } \\
\text { voltaic in- } \\
\text { stallation } \\
\text { area (m) }\end{array}$ & 550 & - & 215 & 170 & 420 & 68 & 450 & 134 & 175 & - \\
\hline $\begin{array}{l}\text { Installation } \\
\text { efficiency }\end{array}$ & $\begin{array}{c}15 \mathrm{kWp} \\
11,7 \%\end{array}$ & - & $\begin{array}{r}24.3 \mathrm{kWp} \\
19,7 \%\end{array}$ & $\begin{array}{c}18 \mathrm{kWp} \\
22,5 \%\end{array}$ & $\begin{array}{c}19 \mathrm{kWp} \\
13,7 \%\end{array}$ & & $25 \mathrm{kWp}$ & $\begin{array}{c}22 \mathrm{kWp} \\
17,3 \%\end{array}$ & $\begin{array}{c}19 \mathrm{kWp} \\
13,5 \%\end{array}$ & - \\
\hline $\begin{array}{l}\text { Installation } \\
\text { cost (Euro) }\end{array}$ & 200.000 & - & 96.000 & 58.000 & 376.200 & & 220.000 & 48.473 & 59.000 & - \\
\hline $\begin{array}{l}\text { Estimate } \\
\text { energy } \\
\text { production } \\
\text { (Kwh/year) }\end{array}$ & 42.500 & - & 26.756 & 18.216 & 62.700 & 8.260 & 62.000 & 23.000 & 22.936 & - \\
\hline $\begin{array}{l}\text { Yearly } \\
\text { profit } \\
\text { (Euro) }\end{array}$ & 9.100 & - & 11.773 & 7286 & 11.286 & & 11.160 & 4.140 & 4.200 & - \\
\hline $\begin{array}{l}\text { Payback } \\
\text { period } \\
\text { (year }\end{array}$ & 21 & - & 9 & 8 & 27 & & 19 & 12 & 14 & - \\
\hline
\end{tabular}

\subsection{Adding a greenhouse}

Adding a greenhouse was considered as a final intervention that can improve both architectural and energy efficiency of the building. A greenhouse is a glass structure that heats up because incoming visible solar radiation (for which the glass is transparent) from the sun is absorbed by floors, walls, and other materials inside of the building. This is a passive solar system in which air warmed by the heat from hot interior surfaces is retained in the building by the roof and wall. In addition, the warmed structures inside the greenhouse re-radiate some of their thermal energy in the infra-red, to which glass is partly opaque, so some of this energy is also trapped inside the glasshouse [4]. When orientation was considered as optimum (south, south-east façade) a greenhouse was added, or existent balconies were closed by glass panes. This intervention was considered in four case studies, which offered the best wall orientation for passive solar gain. This intervention was supposed as a "best practice" intervention in which the high initial investment cost can be justified with a global renovation of the image of the building. By considering that adding quality to architecture can improve not only technical aspects but also social aspects, such as quality of life and safety of inhabitants, it can be said that public administrations and housing company owners can take in consideration the possibility of having an overall improvement of the building, by reaching optimum levels of energy efficiency.

Finally, an evaluation of the passive solar benefits $\left(\mathrm{Kwh} / \mathrm{m}^{2}\right.$ saved by considering greenhouse effect in comparison to the same building without greenhouse) was estimated. As an example, in the case study shown below, the energy saving is $6643 \mathrm{kWh} /$ year, that corresponds to 5154 euro saved each year. 

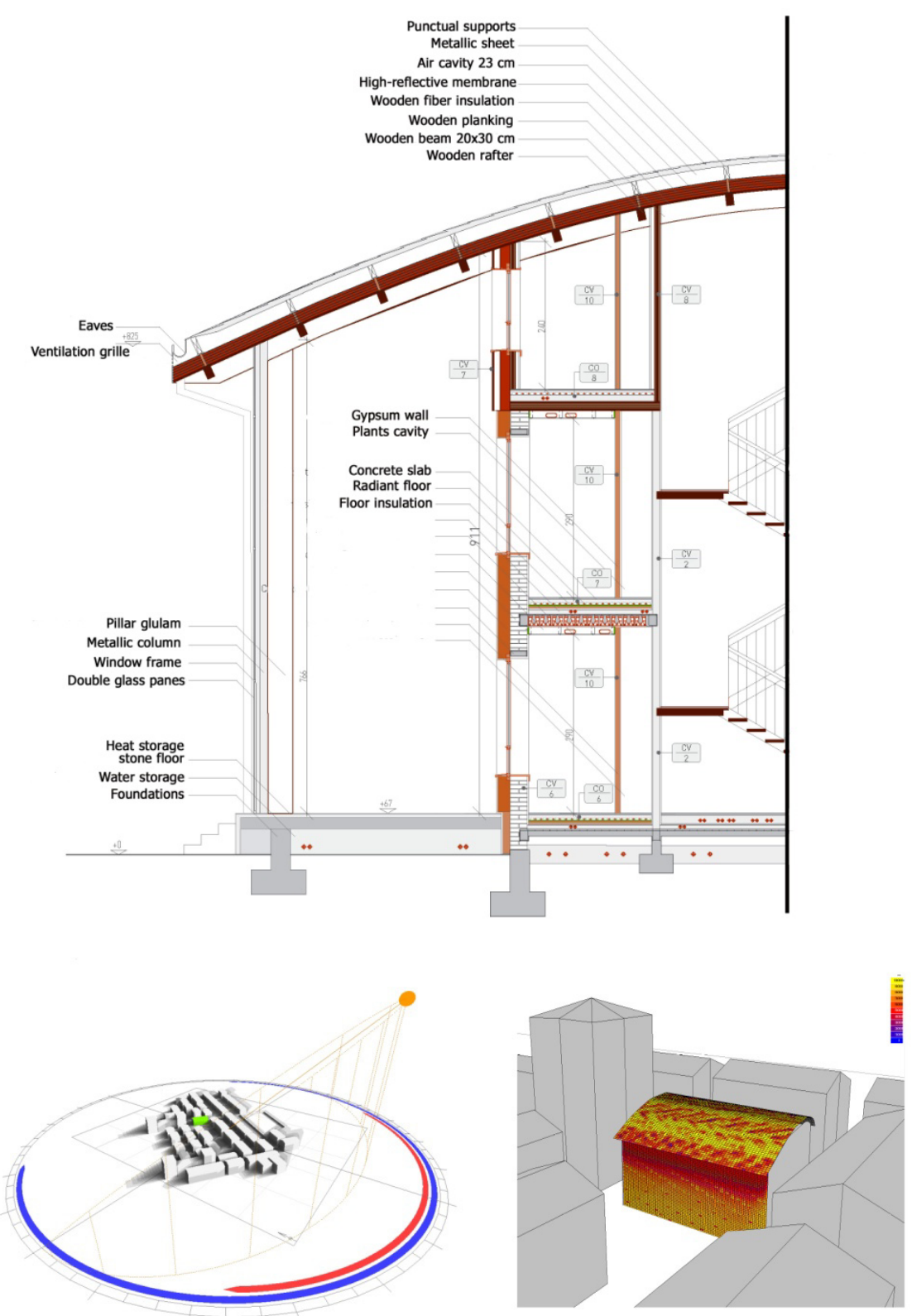

Figure 4: Via Ungarelli building, Ferrara: a new greenhouse addiction.

In terms of energetic class $\left(\mathrm{kWh} / \mathrm{m}^{2}\right.$ year) it can be said that about $25 \mathrm{kWh} / \mathrm{m}^{2}$ year can be saved. 


\section{Conclusions}

The energy failure in social housing building stock of the 1960s-80s in Italy is mainly due to the poor building technologies used, to the plants obsolescence and to the very low maintenance of the edifices. Performing envelopes and renewable energies are the most useful strategies to improve not only the energetic balance, but also the architectural value of these buildings. By considering that housing companies and public administrations carefully evaluates costs and benefits before starting refurbishment interventions, this study can help in determining the advantages of up-to-date technologies in the enhancement of the energetic performance of buildings. This should mean: if the intervention is resalable, convenient, in how many years do I pay back the initial cost. A "best price" to "best practice" strategy can be the guideline that should help in optimizing investments for energy retrofit intervention in public sector.

\section{References}

[1] Brunoro S., Efficienza energetica delle facciate. Standard, requisiti, esempi per l'adeguamento e per la riqualificazione architettonica, Maggioli: S. Arcangelo di Romagna, pp. 28-35, 2006.

[2] Brunoro S., An assessment of energetic efficiency improvement of existing building envelopes in Italy, Management of Environmental Quality. An international Journal, (19)6, pp. 718-730, 2008.

[3] Brunoro S., Sustainable technologies in the refurbishment of existing building envelopes in Italy, Sustainable Constructions, Volume 1, Ios Press: Amsterdam, pp. 257-264, 2007.

[4] Brunoro S., Il contributo delle serre solari nel bilancio energetico dell'edificio, L'Ufficio Tecnico, (7-8)8, pp. 24-29, 2010. 